\title{
CHARACTER VALUES IN THE THEMATIC LEARNING OF ELEMENTARY SCHOOL
}

\author{
Ari Setiawan ${ }^{1 *}$ \\ Syarief Fajaruddin ${ }^{2}$ \\ Makmur Haji Harun ${ }^{3}$ \\ Yohana Sumiyati ${ }^{4}$ \\ C. Indah Nartani ${ }^{4}$ \\ Fitriana Fitriana ${ }^{5}$ \\ ${ }^{1}$ Department of Educational Research and Evaluation, Universitas Sarjanawiyata Tamansiswa \\ ${ }^{1}$ Jl. Kusumanegara No.157, Daerah Istimewa Yogyakarta, Indonesia \\ ${ }^{2}$ Graduate School, Universitas Negeri Yogyakarta \\ ${ }^{2}$ Jl. Colombo Yogyakarta No.1, Daerah Istimewa Yogyakarta, Indonesia \\ ${ }^{3}$ Language and Comunication Department, Universitas Pendidikan Sultan Idris \\ ${ }^{3}$ Tanjong Malim, Perak Darul Ridzuan, Malaysia \\ ${ }^{4}$ Department of Primary School Teacher Education, Universitas Sarjanawiyata Tamansiswa Yogyakarta \\ ${ }^{4}$ Jl. Kusumanegara No.157, Daerah Istimewa Yogyakarta, Indonesia \\ ${ }^{5}$ Islamic Education, Sekolah Tinggi Ilmu Tarbiyah Al Kifayah Riau \\ ${ }^{5}$ Tengkerang Sel., Kec. Bukit Raya, Kota Pekanbaru, Riau, Indonesia \\ E-mail: ari.setiawan@ustjogja.ac.id.
}

Received: November 17, 2020; Accepted: December 2, 2020

\begin{abstract}
The study aims at identifying the character values that appear in the thematic learning of elementary school. The approach that has been adopted in conducting the research is the quantitative approach. The subjects who had been selected using random cluster sampling were 180 students from the elementary schools located in the Province of Yogyakarta Special Region. The study results show that the instrument that has been administered to identify the character values has a high value of content validity. The components that have been established are namely honest, disciplined, responsible, polite, caring, and self-confident.
\end{abstract}

Keywords: character; thematic learning; elementary school

\section{INTRODUCTION}

The development of the curriculum since the implementation of the 2004 Curriculum, which has been based on competence and continued to the 2006 Curriculum (the Educational Unit-Level Curriculum) and the 2013 Curriculum (the latest one), has emphasized characters part of learning results. The internalization of the characters in the elementary school degree is an important component in the learning activity in addition to the cognitive components and the psychomotor components (Miftahudin, 2018; Rismayani, 2020). These components are interrelated from one to another. Three components should be well-balanced, proportional, and well-arranged in elementary education curriculum to support education's success. 
The curriculum of elementary education is arranged to achieve the national educational objectives by paying attention to the stages of the students' character development and the curriculum's compatibility with the environment, the national demands, the development of science and technology, and the art. The elementary school students are considered one of the sources for defining what should be included in the learning materials so that the elementary school students' capability can be developed as optimum as possible. Therefore, how the children grow, develop, and learn and what the children need and what their interests are, should be studied (Majid, 2014). The elementary school students are one integral unity. In this regard, emotional development and social development are equally crucial to intellectual development; thus, these developments should be accommodated in the learning and assessment model.

The learning process in the elementary school degree is part of the efforts to achieve the basic competencies formulated in the curriculum. In the meantime, the assessment activities are performed to measure and assess primary competence achievement. Simultaneously, the assessment is also committed to identifying the strength and weaknesses in the learning process. The assessment results can serve as the basis for the decision-making activities and the revision of the appropriate learning process. Therefore, the excellent curriculum and the sufficient learning process should be supported by a good, well-planned, and continuous assessment system.

Concerning the elementary school degree's learning process, the government has designed the 2013 Curriculum using thematic learning. Thematic learning is one of the available integrated learning models. This thematic learning model involves several subjects to provide the students' learning opportunities to uncover and identify the scientific concepts and principles under the holistic, meaningful, and authentic manners (Majid, 2014). Referring to the statement, the term holistic refers more to the students' angle and emphasizes that all sciences are related from one to another. While the term meaningful means that learning provides values or experiences applicable, and eventually, the term authentic refers more to the fact that the learning results that the students have attained are concrete and practical. The integrated and thematic approach is highly suitable for the development of elementary school students. At this age, the children still regard something as a holistic entity.

The concept of integrated thematic learning focuses on the students as a learner and the processes related to the thinking and the learning development. This learning model emphasizes the analysis of the thinking process and develops the students' thinking skills. During the learning process, the teacher strives to turn the learning process into something relevant and meaningful. The meaningfulness attained will develop the students' characters because the meanings that have been attained come from the learning process related to reality. 
The learning process in the elementary schools that have implemented the 2013 Curriculum uses the integrated thematic model approach. This model demands collaboration between the teacher and the students during the learning process. The students will be assisted in viewing the lessons' relationship and be provided with more varied experiences. In turn, the students are helped to understand the studies attained since the classes are by the concrete conditions. The concrete conditions will teach how the students should behave in the concrete environment, in this case, the social conditions.

According to (Collins \& Dixon, 1999), thematic learning is a learning model that involves several subjects to provide meaningful experiences for the students by relating these subjects to a single theme. Therefore, the students will understand the concepts they learn through direct experiences and the association with the other ideas they have understood. In comparison to the conventional approach, thematic learning engages the students to be more active both mentally and physically within the classroom's teaching-learning activities. The reason is that thematic learning demands the students to be both physically and mentally active about the learning materials that have been distributed, recalling that the learning materials are concrete.

On the other hand, (Meinbach, 2000) state that thematic learning is multidisciplinary learning (which involves numerous subjects) and also multidimensional learning (which involves several aspects such as skills, attitudes, and knowledge). Besides, they also state that thematic learning is designed according to the interest, the skills, and the students' needs. The thematic learning appreciates talents and attitudes so that the thematic learning can be expected to develop the interest, the talent, and the attitude of the students.

Furthermore, Trianto (2016) states that thematic learning is a learning model that combines several learning materials and numerous competence standards and basic competencies from several subjects. The definition implies that thematic learning contains the elements of interdisciplinary and integrated learning concepts. The integrated thematic learning model concept is the result of the idea development by two educational figures, namely Jacob, with his interdisciplinary learning and Fogarty's concept of integrated learning. Therefore, thematic learning can also be defined as a learning approach that intentionally combines several intrasubject and inter-subject aspects (Majid, 2014; Suwandi \& Masruri, 2016). Such a combination will gain knowledge and skills in an integrated manner so that it will be meaningful for the students.

The term meaningful means that through thematic learning, the students will understand the concepts they have directly and concretely studied by associating the intra-subject and the intersubject aspects. Compared to the conventional approach, thematic learning emphasizes the students' engagement in the learning process to be actively involved in the learning process and, 
thus, the decision-making process. The reason is that the learning process is more directed toward the concrete examples in daily life or the criteria in which the learning materials are closely introduced into the students' everyday lives.

Regarding the meaning and the theme of thematic learning, (Rusman, 2011) states that the integrated learning that benefits the thematic approach, which involves several subjects, provides meaningful experiences. When the learning process is significant, the students will understand the concepts they have learned through the direct experience and associate this concept with another idea that they have known within the thematic learning process. On the other hand, according to (Hidayat \& Wardan, 2013), thematic learning is integrated learning that benefits the theme as the unifying material that has been found in several subjects and delivers the unifying material from several subjects into a single learning unit (Indra \& Lumintuarso, 2014). The thematic learning is delivered coherently from several subjects that have been packed into a single theme.

Thematic learning can be considered a learning model involving several subjects to provide meaningful experiences for the students. The learning model's integrity can be viewed from the process, the curriculum, and the teaching-learning activities (Majid, 2014). Therefore, it can be concluded that thematic learning is integrated learning that benefits them as a unifying material from several subjects in a single meeting.

Integrated thematic learning is a learning model that centers on the students, delivers direct experiences, and separates the subtle relationship among subjects. The concepts from numerous subjects are presented in a single meeting, and the learning process may develop according to the students' real conditions. This type of learning will trigger the appearance of numerous situations and conditions that have been woven harmoniously between the students and the teachers.

The integrated thematic approach from numerous reviews are namely: (1) the holistic approach, which combines the aspects of epistemology, social, and psychology; and (2) the pedagogic approach, which aims at educating the students through the connection between the mind and the body, between the person and the personality, between the individuals and the community, and also between the domains of science. This approach is perfect for the students because it combines numerous aspects and pays attention to their real conditions.

In the meantime, thematic learning can also be considered as an approach that has an orientation toward the learning practice based on the student's need. This type of learning departs from the learning theory that rejects drill as the basis for forming the students' intellectual structure and knowledge. The reason is that a learning process should be meaningful and should emphasize the importance of the learning program that displays the orientation toward the needs of the students' development. The term of development, in this regard, does not only refer to cognitive 
development but also affective and psychomotor development. The statement also applies to the meaning in the sense of the students' character development.

However, the characters that become the core of the education that aims to create a generation of morals have not been given good attention due to the teachers' limitations, especially in selecting the appropriate characters. The teachers tend to spend their time teaching and viewing the students' cognitive aspects rather than paying attention to the students' character development. A study by Kartinah (2018) shows that the practice of learning results assessment in the school, especially in the elementary school degree, is only accustomed to measuring the knowledge aspects. The ranks show the students' appreciation and the test scores, whereas the combination between the knowledge and the characters (the affective aspects) will improve the students' quality in the classroom (Brown et al., 2005; Locke \& Latham, 2006). Although all educators are aware that there are cognitive, affective, and psychomotor domains (behaviors) in education, in practice, those aspects have not been given sufficient attention, especially in terms of assessment among the students (Handayani, 2017; Khilmiyah et al., 2015).

The teachers are not accustomed to assessing the students' characters' changes in the elementary school degree. This situation persists not because of the educators' unwillingness but because of the educators' lack in describing or identifying the students' characters. Consequently, the assessment of the students does not describe the students' character thoroughly. About the statement, the teachers must identify numerous characters that appear in thematic learning. This matter becomes the basis for the necessity to conduct a review and a study to identify the students' characters that might appear in the thematic learning within the elementary school degree.

\section{METHOD}

The study was quantitative research, and the objective of the study was to identify the characters that had appeared in the integrated thematic learning at the elementary school degree. The approach adopted in the study was the exploratory method since, through the study, the researchers would like to attain the components of the characters. The research procedures were briefly elaborated in the flowchart that had been displayed in Figure 1.

At the beginning of the study, the researchers conducted a preliminary study to Muhammadiyah Elementary School Papringan and Kaliagung Elementary School Sentorol. The initial study results were processed to attain the description of the thematic learning and the character values that had appeared. After visiting the two elementary schools, the researchers conducted a library study comprehensively to develop the definition of the students' characters' concept. 
Then, in the subsequent stage, the researchers designed an instrument of the character using the summative rating scale by modifying the Likert Scale. The summative rating scale was used to identify the characters' components that had appeared in thematic learning. The alternatives that had been selected were Often (OF), Occasional (OC), Rare (R), and Never (N) with the scoring 4 $3-2-1$ for every favourable item and with the scoring $1-2-3-4$ for every unfavourable item. Furthermore, the instrument that had been designed was validated through expert judgment. In this occasion, the experts reviewed all the statements, both qualitative and quantitatively. The qualitative review was conducted using the Delphi Method (Linstone, 1985; Linstone \& Turoff, 1976). The conduct of the Delphi Method involved some experts, namely an expert of elementary school learning, an expert of testing and assessment, an expert of character education, a psychiatrist, a teacher representative, and a student representative. In the meantime, the quantitative review was conducted by using the content validity, namely the Aiken's formula. The implementation of Aiken's formula was elaborated more in the data analysis sequence.

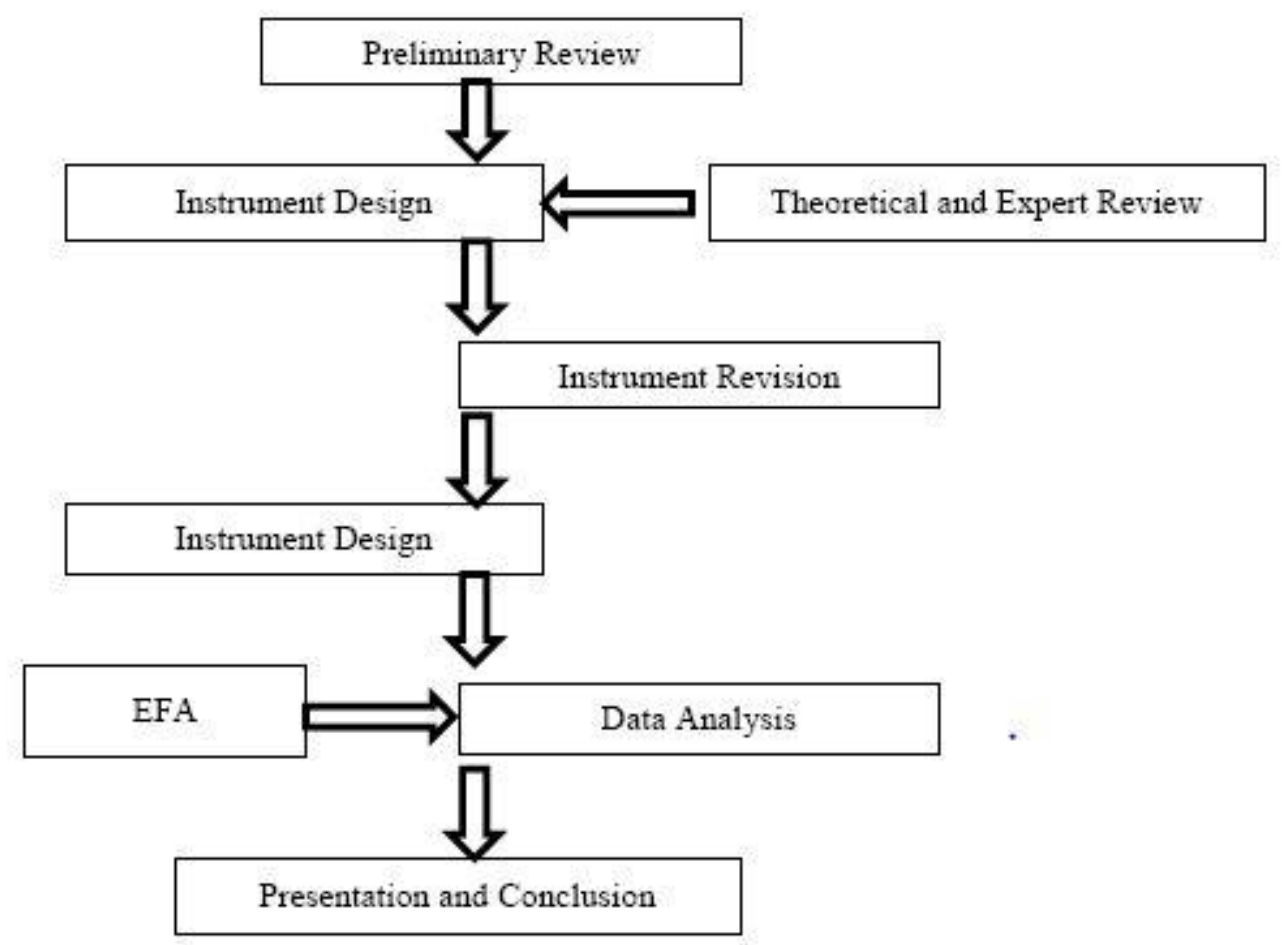

Figure 1. The Procedures of the Character Value Identification Instrument Development

After the instrument had been revised, the final version of the instrument was attained. The final instrument was implemented in the data gathering activities from five elementary schools. The data gathering process involved 180 students who had been the population in the study. The response data from the elementary school students' characters were analyzed, and the analysis included the item validation using the EFA with the assistance from the SPSS Version 20.0 Program. Implementing the EFA technique in the data analysis was intended to identify the 
number of the components and items that had been valid. About the validity, the reliability of the instrument was confirmed by using Cronbach's alpha formula.

\section{RESULT AND DISCUSSION}

At the preliminary stage of the study, the preliminary version of the instrument intended to identify the students' character values was designed. This instrument was developed based on the literature review, the field review, and expert judgment. In the preliminary stage of the study, an instrument was attained with 12 indicators and 24 items. After having been designed, the instrument was estimated by using the content validity with the Aiken approach.

Table 1. Results of Item Fitness Aiken Index with the Indicators of the Instrument

\begin{tabular}{|c|c|c|c|}
\hline Indicators & Item & Aiken's Index & Criterion \\
\hline \multirow[t]{2}{*}{1} & Item 1 & 0.833 & High \\
\hline & Item 2 & 0.917 & High \\
\hline \multirow[t]{2}{*}{2} & Item 1 & 0.833 & High \\
\hline & Item 2 & 0.917 & High \\
\hline \multirow[t]{2}{*}{3} & Item 1 & 1.000 & High \\
\hline & Item 2 & 1.000 & High \\
\hline \multirow[t]{2}{*}{4} & Item 1 & 1.000 & High \\
\hline & Item 2 & 0.917 & High \\
\hline \multirow[t]{2}{*}{5} & Item 1 & 1.000 & High \\
\hline & Item 2 & 1.000 & High \\
\hline \multirow[t]{2}{*}{6} & Item 1 & 1.000 & High \\
\hline & Item 2 & 1.000 & High \\
\hline \multirow[t]{2}{*}{7} & Item 1 & 0.833 & High \\
\hline & Item 2 & 0.833 & High \\
\hline \multirow[t]{2}{*}{8} & Item 1 & 0.833 & High \\
\hline & Item 2 & 0.917 & High \\
\hline \multirow[t]{2}{*}{9} & Item 1 & 1.000 & High \\
\hline & Item 2 & 1.000 & High \\
\hline \multirow[t]{2}{*}{10} & Item 1 & 1.000 & High \\
\hline & Item 2 & 0.833 & High \\
\hline \multirow[t]{2}{*}{11} & Item 1 & 1.000 & High \\
\hline & Item 2 & 1.000 & High \\
\hline \multirow[t]{2}{*}{12} & Item 1 & 1.000 & High \\
\hline & Item 2 & 1.000 & High \\
\hline
\end{tabular}

Based on the results in Table 1, it is clear that all items in the category have been valid. The validity has been confirmed by the results of the Aiken's Index, which shows that all items $>0.80$. These results confirm that the instrument items have a good validity level and are fit for implementation. Concerning the statement, content validity refers to the test that measures how far an instrument has represented all aspects as a conceptual framework or whether the contents or the substances of the measurement have represented the loadings in the form of the traits that should be measured. The items in a test should be considered regarding the representativeness of the 
relevant materials. It means that every single item should be assessed in terms of relevance with the traits under assessment.

Validity indicates that a test is essentially valid as long as it detects and measures what it alleges to measure and not something else (Angoff, 1988; Carmines \& Zeller, 1979; Thorndike et al., 1991). According to (Urbina, 2016), instrument validity entails what should be measured from an instrument and how good it is in measuring the given traits. Therefore, validity can be defined as the agreement between test score or measure and the quality it is believed to measured (Kaplan \& Saccuzzo, 2017; Setiawan \& Astuti, 2018). In other words, validity has been defined as the extent to which a test measures what it was designed to measure (Aiken, 2000).

From another perspective, validity can be defined as an aspect of measurement accuracy (Azwar, 2015a). Accuracy becomes important in a measurement. The measurement accuracy will result in inaccurate data. It can be concluded that validity can be briefly translated into "precision" and "accuracy," namely how far an instrument can measure or has successfully measured the intended traits or how far an instrument has fulfilled its measurement functions.

A valid measurement tool cannot only uncover the data accurately but also provide an accurate description of the data. Accurate means that the measurement can describe the slightest differences from one subject to another (Sunyoto, 2012).

Content validity can also refer to the aspect of appropriateness. According to (Kumaidi, 2014), content validity is the adequacy of a test's content represents the content of the assessment domain about which inferences are to be made. The statement confirms that the description of the sampled behaviours that have been intended to measure becomes the evidence of appropriateness. Thus, the guidelines of an instrument will be decisive, and the verification of the instrument demands the agreement on the results of the review by the experts from the domains of measurement.

Furthermore, the results of the construct validity test are analyzed by using the EFA approach. The preliminary step in this stage is performing the KMO Bartlett's Test to identify the sample sufficiency. The results of the KMO Bartlett's Test show is 0.832 , which implies that the samples are from the population with the same variance. Then, to identify the item validity, the anti-image correlation value can be used, and the anti-image correlation value is attained from the results of the EFA Analysis, which range from 0.5 to 0.9. Overall, these results show that the items of the instrument have been valid and fit for implementation.

After the EFA analysis results have been attained, the subsequent step is defining the eigenvalue to identify the factors or the components that have been shaped. The results of the eigenvalue calculation are provided in Table 2. From the results in Table 2, it can be concluded that the instrument under analysis has yielded six components. These components have been identified as the character values in the thematic learning of the elementary school degree. 
Table 2. Results of the Eigenvalue Calculation for the Instrument

\begin{tabular}{|c|c|c|}
\hline No. & Components / Factors & Eigen Value \\
\hline 1. & Honesty & 7.562 \\
\hline 2. & Discipline & 1.639 \\
\hline 3. & Responsibility & 1.517 \\
\hline 4. & Politeness & 1.272 \\
\hline 5. & Caring & 1.201 \\
\hline 6. & Self-confident & 1.035 \\
\hline
\end{tabular}

After the validity estimation has been completed, the reliability test for the instrument should be performed. The results of the reliability test by using Cronbach's Alpha is 0.88 . This result shows that the instrument has been reliable. Regarding the statement, the measurement tool reliability and the measurement results reliability are usually defined similarly. However, the use of each aspect should be given specific attention. The concept of reliability in the measurement tool reliability is highly associated with the error of measurement. The measurement error error refers to how far the measurement results' inconsistency will occur if the measurement is performed again on the same subjects. One of the causes behind the error of measurement is the variation in the respondents' responses (Viswanathan, 2005). For example, there is an extreme response in which an item has been massively responded. In this case, the high reliability implies the low error of measurement and vice versa (Coaley, 2014). Concerning the statement, the error of measurement should be given attention to attain high instrument reliability.

Reliability correlates between an item scale and all responses to the item scale (Robinson et al., 2013). The concept of reliability refers to how far the measurement process results are trustworthy (Azwar, 2015b). The reliability estimates of an instrument are calculated using the internal consistency approach through the administration of Cronbach's alpha formula. The formula is implemented based on the non-interrogative responses; instead, the formula is implemented more based on gradation, which can be attained from the criteria of the responses. A reliable instrument's requirement is I the combined coefficient of the item (Alpha Reliability) is 0.70 (Mardapi, 2012; Nunnaly, 1981; Sunyoto, 2012) or higher, then the instrument is reliable. The clarificatory item will be the evidence that the instrument that has been administered is reliable.

The final stage of the study was named the components that had been established. The naming itself referred to the agreement between the teachers, the experts, and the 2013 Curriculum implemented in the thematic approach. Thus, the names of the components that have been established are honesty, disciplined, responsible, polite, caring, and self-confident.

The definition of the instrument of the character identification has departed from Aiken's index, specifically on the instrument developed for the identification of the character values. The results of the Aiken's index range between $0.8333-1.000$, which implies that the items in the 
instrument that has been developed are highly valid. This finding is by the opinion of (Retnawati, 2016), which states that if the index is lower than or equal to 0.4 , then the instrument validity is low if the index ranges between 0.4 and 0.8 validity is moderate. If the index is higher than 0.8 , then the instrument validity is very high. Content validity is essential in the development of both attitude measurement and attitude assessment.

After the content validity has been confirmed by using the Aiken's index, the character identification is performed by viewing the components established in the factor analysis using the Exploratory Factor Analysis (EFA) technique. The administration of EFA is proceeded by performing the KMO Bartlett's test first, and the results of the KMO Bartlett's test are equal to 0.832 or higher than 0.5 . As a result, it can be concluded that the samples that have been involved are already sufficient (Retnawati, 2016). At the same time, it can also be concluded that the instrument that will be administered for identifying the affective components can be analysed further.

The subsequent analysis results are intended to identify the construct validity of the instrument that has been designed. In this regard, the validity test aims to identify how far the instrument can capture a capability or a theoretical construct that should be measured (Fernandes, 1984; Nunnaly, 1981). The statement is apparent from the anti-image correlation value in which the performed EFA results that the $\mathrm{x}$ range is between 0.5 and 0.9. In other words, the EFA value that ranges between 0.5 and 0.9 implies that the instrument is valid and fit for implementation. Another requirement used as a reference is the MSA value with 0.50 as the minimum requirement. This loading factor becomes the reference in making decisions over the valid items (Setiawan et al., 2019).

After all, items have been declared valid, and based on the results of the study, it can be defined that six components have been established. The statement is based on the eigenvalues that have been found in the lowest score of 1.035 and the highest score of 7.562. The cluster of these components is later named the character values. Then, based on the experts' discussions and the distribution of the items in the components, the six components are named honest, disciplined, responsible, polite, caring, and self-confident. These components are generally known as characters of Core Competency 2 Characters for the elementary school students.

\section{CONCLUSION}

Based on the results of and the discussions in the study, several conclusions can be drawn. First, the instrument that has been administered to identify the elementary school students' character values has already met the requirements of both validity and reliability. The content validity has been measured using the Aiken's index ranges between 0.8 and 1.0, while the 
construct validity as having been measured using the EFA approach is higher than 0.50 . On the contrary, the reliability as having been measured by using the Alpha approach is 0.88 . Second, for identifying the character values, six components have been established based on the eigenvalues that have been calculated. The components found are later named as the elementary school students' character values in thematic learning, and these character values consist of honesty, discipline, responsibility, politeness, caring, and self-confidence.

\section{REFFERENCES}

Aiken, L. R. (2000). Psychological testing and assessment. Pearson.

Angoff, W. H. (1988). Validity: An evolving concept. Lawrence Erlbaum Associates, Inc.

Azwar, S. (2015a). Reliabilitas dan validitas. Pustaka Pelajar.

Azwar, S. (2015b). Skala pengukuran sikap manusia. Pustaka Pelajar.

Brown, U. J., Park, Y., \& Jung, S. (2005). The effects of students' knowledge and attitude on the classroom performance. Research in Higher Education Journal, 1-8.

Carmines, E. G., \& Zeller, R. A. (1979). Reliability and validity assessment (Vol. 17). Sage publications.

Coaley, K. (2014). An introduction to psychological assessment and psychometrics. Sage.

Collins, Gillian., \& Dixon, Hazel. (1999). Integrated learning: Planned curriculum units. Bookshelf Pub. Australia.

Fernandes, H. J. X. (1984). Evaluation of educational programs. Jakarta: National Education planning evaluation and curriculum development.

Handayani, S. (2017). Peningkatan profesional guru melalui komunikasi informal. Sekolah Dasar: Kajian Teori dan Praktik Pendidikan, 24(1), 91-97.

Hidayat, S., \& Wardan, A. S. (2013). Pengembangan kurikulum baru. Remaja Rosdakarya.

Indra, G., \& Lumintuarso, R. (2014). Peningkatan hasil pembelajaran lari sprint 60 meter melalui metode permainan SDN 009 Teluk Pelalawan. Jurnal Keolahragaan, 2(2), 155-169. https://doi.org/10.21831/JK.V2I2.2611

Kaplan, R. M., \& Saccuzzo, D. P. (2017). Psychological testing: Principles, applications, and issues. Nelson Education.

Kartinah, K. (2018). Pengembangan instrumen pengukuran disiplin untuk siswa sekolah menengah pertama. Wiyata Dharma: Jurnal Penelitian dan Evaluasi Pendidikan, 6(2), 102-108.

Khilmiyah, A., Sumarno, S., \& Zuchdi, D. (2015). Pengembangan model penilaian keterampilan intrapribadi dan antarpribadi dalam pendidikan karakter di sekolah dasar. Jurnal Penelitian dan Evaluasi Pendidikan, 19(1), 1-12. https://doi.org/10.21831/pep.v19i1.4550

Kumaidi, K. (2014). Validitas dan pemvalidasian instrumen penilaian karakter. Seminar Psikometri Fakultas Psikologi Universitas Muhammadiyah Surakarta.

Linstone, H. A. (1985). The Delphi technique. Environmental Impact Assessment, Technology Assessment, and Risk Analysis (621-649). Springer Berlin Heidelberg. https://doi.org/10.1007/978-3-642-70634-9_22

Linstone, H. A., \& Turoff, M. (1976). The Delphi method: Techniques and applications. Technometrics, 18(3), 363. https://doi.org/10.2307/1268751

Locke, E. A., \& Latham, G. P. (2006). New directions in goal-setting theory. Current Directions in Psychological Science, 15(5), 265-268. https://doi.org/10.1111/j.1467-8721.2006.00449.x 
Majid, A. (2014). Pembelajaran tematik terpadu. Remaja Rosda Karya.

Mardapi, D. (2012). Pengukuran penilaian dan evaluasi pendidikan. Nuha Medika.

Meinbach, A. Meyer., Rothlein, Liz., \& Fredericks, A. D. (2000). The complete guide to thematic units: Creating the integrated curriculum. Christopher-Gordon Publishers.

Miftahudin, M. (2018). Penanaman sikap spiritual dan sosial peserta didik pada Kurikulum 2013 SMA Negeri 2 Kebumen. IAIN Purwokerto.

Nunnaly, J. C. (1981). Psychometric theory. Tata Mcgraw Hill Publishing Company Limited.

Retnawati, H. (2016). Validitas reliabilitas dan karakteristik butir. Parama Publishing.

Rismayani, L. D. (2020). Penanaman sikap sosial melalui pembelajaran IPS pada siswa kelas VII SMP Negeri 2 Singaraja. Jurnal Pendidikan IPS Indonesia, 4(1), 8-15.

Robinson, J. P., Shaver, P. R., \& Wrightsman, L. S. (2013). Measures of personality and social psychological attitudes: Measures of social psychological attitudes (Vol. 1). Academic Press.

Rusman, R. (2011). Model-model pembelajaran: Mengembangkan profesionalisme guru. Rajawali Pers.

Setiawan, A., \& Astuti, W. (2018). Development of children's anxiety test special needs. Proceeding International Seminar on Education, $O(0)$.

Setiawan, A., Fajaruddin, S., \& Andini, D. W. (2019). Development an honesty and discipline assessment instrument in the integrated thematic learning at elementary school. Jurnal Prima Edukasia, 7(1), 9-19. https://doi.org/10.21831/jpe.v7i1.23117

Sunyoto, D. (2012). Validitas dan reabilitas dilengkapi analisis data dalam penelitian kesehatan. Nuha Medika.

Suwandi, I. K., \& Masruri, M. S. (2016). Pengembangan picture book sejarah nasional dengan pendekatan tematik terpadu untuk kelas IV sekolah dasar. Jurnal Prima Edukasia, 4(1), 79. https://doi.org/10.21831/jpe.v4i1.7747

Thorndike, R. M., Cunningham, G. K., Thorndike, R. L., \& Hagen, E. P. (1991). Measurement and evaluation in psychology and education. Macmillan Publishing Co, Inc.

Trianto, T. (2016). Desain pengembangan pembelajaran tematik: Bagi anak usia dini. Kencana Prenada Media Group.

Urbina, S. (2016). Psychological testing. Encyclopedia of Mental Health (357-364). Elsevier. https://doi.org/10.1016/B978-0-12-397045-9.00219-6

Viswanathan, Madhu. (2005). Measurement error and research design. Sage Publications. 